\title{
Teaching Reading Strategies as the Key to Academic Success
}

\author{
L. V. Knyshevytska, N. P. Bezpalova \\ Division of the English Language, Department of Law and International Relations, Borys Grinchenko \\ Kyiv University, Kyiv, Ukraine \\ Corresponding author. E-mail: 1.knyshevytska@kubg.edu.ua,n.bezpalova@kubg.edu.ua
}

Paper received 31.01.19; Accepted for publication 13.02.19.

\section{https://doi.org/10.31174/SEND-PP2019-188VII77-07}

\begin{abstract}
In recent years, universities place a more heavy emphasis on developing the ability of ESL/EFL students to read specialized authentic academic texts in order to be successful in the programs of study. In this light, raising awareness of cognitive and metacognitive strategies that the students can use in completing their reading assignments seems to be of crucial importance. The present study examines cognitive and metacognitive reading strategies of EFL students. The data for this study were collected by means of a reading strategies survey. The correlation analysis and t-tests demonstrated that gender correlates with the use of cognitive and metacognitive reading strategies. The results of the findings revealed that, in general, females used slightly more often cognitive and metacognitive reading strategies than males. The study clearly indicates the need for teaching and raising awareness of cognitive and metacognitive reading strategies of the ESL/EFL students as the ones directly involved in cognitive processing of the academic reading materials. In addition, the study generally showed that gender influences selection and use of reading strategies. This fact could have implications for successful reading group activities where both genders would complement each other in the application of text processing skills.
\end{abstract}

Keywords: Reading, metacognitive strategies, cognitive strategies, ESL/EFL, gender, SPSS analysis

Introduction. Reading complex academic texts is a crucial priority for ESL/EFL students who are enrolled in various higher education programs. However, their general knowledge of English does not at all guarantee that the students will be successful in coping with complex, authentic academic reading genres required of them by the syllabi. As instructors of English who teach classes the curriculum of which are closely associated with working with various genres of readings in academic contexts, we can not help but notice that our students in majority are experiencing difficulties in completing reading assignments. This might be due to the lack of familiarity either with the genre of academic reading, low reading ability in a second language in general, or lack of awareness of reading strategies that are necessary in order to cope with the academic reading tasks. Therefore, it is crucial to investigate to what degree our male and female EFL students are familiar with the cognitive and metacognitive reading strategies, what strategies they generally use, and to what degrees. The present study was conducted in order to ramify this stance with academic reading and help ESL students to raise their awareness of the reading strategies in academic contexts.

Review of Literature. The theoretical research in cognitively complex process of reading has a long history and covers a variety of topics that can be applied to second language acquisition as well. Thus, Goodman's (1970) seminar article, "Reading: A psycholinguistic Guessing Game", discusses bottom-up and top-down processing theory. Bottom-up processing, relates to "linguistic data processing mechanisms", where the readers have to identify various linguistic signals and arrange them in a certain sequence [12]. Bottom-up processing focuses on decoding letters in a word, words in a phrase, sentences in a discourse. Top-down processing, on the other hand, engages the learners' "intelligence and experience in the process of understanding the text" [12]. The reader infers the meaning of the unknown words and phrases from whole context of the text in a manner of a guessing game. Thus, reading, according to Goodman (1967), is a "puzzle-solving process", where readers have to "decide what to retain and not to retain, and move on" [3]. Therefore, ESL learners need to master reading skills using both pro- cesses simultaneously and in the appropriate situation to succeed in academia.

Various studies have been done in attempt to classify reading strategies that can be used by $\mathrm{L} 2$ readers that reflect Goodman's top-down, bottom-up processing theory (e.g. Anderson, 1991; Block, 1986; Pritchard, 1990). [1; $16 ; 2]$. Block's coding system relates reading strategies to two levels: general comprehension and local linguistic strategies. General comprehension strategies include methods used for "comprehension-gathering" and "comprehension-monitoring" [16]. These strategies are classified as top-down, reader-centered strategies. Local linguistic strategies are concerned with the reader's attempt to understand specific linguistic units. These would be regarded as bottom-up, text-centered strategies.

Another aspect of reading comprehension is related to the theory of schemas (Clarke \& Silberstein, 1977; Carell, 1987; Carrell \& Eisterhold, 1983; Widdowson, 1983; Carrell, Pharis \& Liberto, 1989) [9; 6; 4; 18; 5 ]. Schemata, or schema, have been described by Widdowson, 1983 as "cognitive constructs which allow for the organization of information in long-term memory" [18]. Researchers Carrell \& Eisterhold (1983), identified three types of schemata: content, formal and linguistic. Content schema provides the reader with background knowledge; formal schema is associated with the knowledge of different genres, language structures, and it deals with text organization, vocabulary and grammar [4] . Finally, linguistic schema allows the reader to identify even the unknown words from the specific way of their collocation. All three schemata are of outmost importance for successful reading comprehension.

The current research in learning strategies in ESL and EFL settings has focused on cross-cultural aspects of using and teaching second language learning strategies (Levine, Reves \& Leaver, 1996; Dreyer \& Oxford, 1996 ) $[14 ; 11]$, considered the influence of gender and motivation on strategy use (Kaylani, 1996) [13] and discussed methods of teaching strategies in EFL settings (Dadour \& Robbins, 1996; Chamot, Barnhardt, El-Dinary \& Robbins, 1996) [7; 10]. Among these topics, the issue of teaching specific academic-related language strategies in university and college settings (Chamot \& O' Malley, 
1996) plays a very important role in order for the students to succeed [8]. Thus, teaching reading strategies seems an indispensable part of success in various academic programs.

Reading is a complex process that involves aspects of cognition (the ability to comprehend the text) and metacognition (the strategic ability to manipulate the text in order to achieve a particular goal). Both aspects are crucial in understanding the academic text. Various factors may influence the readers' metacognitive knowledge including "previous experiences, beliefs, culture- specific instructional practices, proficiency in L2" [17]. Sheorey \& Mokhtari (2001) further point out that "the combination of conscious awareness of the strategic reading process and actual utilization of reading strategies distinguishes the skilled from unskilled readers" [17].

Research on examination of metacognitive and cognitive awareness of reading strategies among native and non-native readers in ESL or EFL settings (Sheorey \& Mokhtari, 2001: Mokhtari \& Sheorey, 2002) focused on reading academic texts, such as textbooks among high school and college students $[17 ; 15]$. However, very few studies had been done that examine cognitive and metacognitive strategies of college and university ESL students, focusing specifically on a particular reading genre of academic scholarly journal articles.

Research Question and Hypothesis. The present study takes up this question investigating the perceptions of cognitive and metacognitive awareness of EFL university students. More specifically, we hypothesized that gender would be a significant factor in selection of cognitive and metacognitive reading strategies.

Method. The participants in this study were $36 \mathrm{EFL}$ students (18 females, 18 males) enrolled in classes that focus on developing academic reading and writing skills . In these classes, the students were involved in a variety of reading and writing tasks that included reading of a wide range of academic journal articles as a part of their preparation for writing secondary and empirical research studies.

The data for this study were collected by means of a reading strategies survey modified from the original Metacognitive-Awareness-of-Reading-Strategies Inventory (MARSI) developed by Sheorey \& Mokhtari [17] . The modified version was used because reading journal articles requires use of specific reading strategies. The specific strategies (cognitive and metacognitive) were selected based on the whole class discussions of students' use of reading strategies. The students were given an academic journal article to read and then were interviewed on the use of their reading strategies. The survey was developed to determine cognitive and metacognitive reading strategies of non-native speakers of English.

The collected data on 29 reading strategies were analyzed, using quantitative method of analysis (SPSS). The analysis focused on the following variables: gender, preference for cognitive and metacognitive strategies, and tendency and degree of each reading strategy use. In the course of analysis, using frequency distribution, t-test method, and correlation analysis of cognitive and metacognitive strategies the following statistics were reported: mean, standard deviation, and the percentage of use for each strategy. The reliability coefficient for overall items, metacognitive items, and cognitive items were determined.
Results. The analysis of the basic descriptive statistics for each reading strategy showed that the most frequently used strategy was a metacognitive one: "I look at the title before reading the text to get a hint about its content" (M $=4.97, \mathrm{SD}=1.118)$, followed by the second frequent cognitive strategy "I reread the text to help me understand it better" $(\mathrm{M}=4.86, \mathrm{SD}=1.337)$. The third most frequently used strategies were cognitive strategies: "I try to get back on track when I lose concentration" $(\mathrm{M}=4.78$, $\mathrm{SD}=1.109$ ) and "When the text becomes difficult, I start reading it carefully" $(\mathrm{M}=4.78, \mathrm{SD}=1.058)$. The least frequent strategy was a metacognitive reading strategy: "I discuss what I read with others to check my understanding" $(\mathrm{M}=2.46, \mathrm{SD}=1.192)$, followed by a metacognitive strategy "I take notes while reading to help me understand what I read" $(\mathrm{M}=3.05, \mathrm{SD}=1.508)$. The third least frequently used strategy was a cognitive strategy: "I translate the text I read into my native language to understand it better" $(\mathrm{M}=3.16, \mathrm{SD}=1.444)$. The overall mean of the items in the survey was $\mathrm{M}=4.04$, with minimum mean $(\mathrm{M}=2)$ and maximum mean $(\mathrm{M}=5)$.

The coefficient of internal reliability (Cronbach's Alpha) of the instrument was .878 , which is relatively high. This means that all the respondents' answers were consistent and trustworthy, indicating that the repeated application of the survey would produce similar results. Furthermore, a t-test was used to analyze the difference between the gender and the frequency of strategy use. The .05 alpha level of significance was established for testing. The calculated t-value was $-1.243(\mathrm{p}=.222)$. The $\mathrm{p}$-value for this t-test indicates that there was no statistical significance between the two means; that is, both genders showed similar number of reading strategies use, even though female mean $(M=4.17)$ was slightly higher than the mean of males $(\mathrm{M}=3.92)$.

The strategies were divided into metacognitive and cognitive, and a t-test was used to analyze the correlation between male and female genders and strategies use. At the alpha level of .05 , the calculated t-value for the use of cognitive strategies by male was $-.550(\mathrm{p}=.586)$ and the use of cognitive strategies by female was $-.554(\mathrm{p}=.583)$. These t-test results indicate that there was no statistical significance of reading strategies between the mean of male $(M=3.9474)$ and the mean of female $(M=4.0794)$ participants. The calculated $t$-value for metacognitive strategies was for male $-1.663(\mathrm{p}=.105)$ and for female $1.681(\mathrm{p}=.103)$ at the alpha level .05 . These t-test results indicate that there was slightly higher significance in the use of metacognitive strategies in male $(M=3.8877)$ than female $(M=4.2593)$. Thus, these statistical data indicate that females overall used strategies slightly more often than males. The correlation between the use of cognitive and metacognitive strategies was $\mathrm{r}=.581 ; \mathrm{p}<.01$, indicating a moderate significant linear relationship. The reliability coefficient for metacognitive items calculated by Cronbach's Alpha was .8171 and for cognitive strategies .8155. Both coefficients show high reliability; however, the reliability of the metacognitive strategies was slightly higher.

Discussion and Conclusion. The objective of this study was to examine the use of metacognitive and cognitive reading strategies of male and female university EFL students. More specifically, this study focused on reading strategies of university EFL students enrolled in classes 
with the emphasis on research, in which the students were reading academic journal articles.

The results revealed that, in general, females used slightly more often cognitive and metacognitive reading strategies than males. More specifically, for example, the mean difference between the use of metacognitive reading strategies among males and females was slightly greater than the mean difference between the uses of cognitive reading strategies across genders. The findings further indicate that females used slightly more metacognitive reading strategies than cognitive strategies, and males use more often cognitive strategies than metacognitive ones. That males used fewer metacognitive reading strategies might indicate that they might be better in top-down processing mechanisms, that is in identifying various linguistic signals and arranging them in a sequence of a successful reading problem solving. In addition, males affectively compensate for strategic manipulation of the text by using various cognitive strategies such as activating their background knowledge or schemata.

In contrast, as one could infer from the results, females are more detail oriented that males and prefer bottom-up processing of information. That is, they tend to use diverse factors, such as life experiences, cultural knowledge and situational sensitivity during the reading process. They have a better strategic ability and employ metacognitive strategies in order to comprehend the text in a slightly larger degree than males. This gendered approach to selection and use of cognitive and metacognitive read- ing strategies could have useful implications for successful reading group activities in which both genders would complement each other in the application of text processing skills.

The results also showed that all the participants used metacognitive and cognitive strategies linearly. That is, when the participants read academic journal articles, they used a similar number of metacognitive and cognitive strategies. Such discovery indicates that reading academic journal articles requires both types of strategies in order to comprehend the texts.

The fact that the correlation of cognitive and metacognitive strategies across genders was not statistically significant might be explained by the relatively small number of participants $(n=36)$. More correlational studies need to be done among gender, cultural, and educational variables. Finally, participants mainly were EFL students coming from Ukraine; therefore, the findings might vary with the different population or settings.

The results of this study, however, can not be conclusive. Even though the outcome of this study does indicate that females in general used more reading strategies, it does not suggest that males are not aware of these strategies. Instead, males may not use them when needed. In addition, the use of reading strategies may not guarantee that students would still understand the text. More research has to be conducted with a larger number of participants, addressing the use of cognitive and metacognitive reading strategies in academic settings.

\section{REFERENCES}

1. Anderson, N.J. (1991).Individual differences in strategy use in second language reading and testing. Modern Language Journal, 75, 460-472.

2. Block, E. (1986). The comprehension strategies of second language readers. TESOL Quarterly. 20, 463-494.

3. Brown, H.D. (2001). Teaching reading. In Teaching by principles. An interactive approach to language pedagogy (pp. 298-334). Longman.

4. Carrell, P. \& Eisterhold, J. (1983). Schema theory and ESL reading pedagogy. In Interactive Approaches to Second Language Reading. (pp. 73-92). Cambridge: Cambridge University Press.

5. Carrell, P.L. (1987). Content and formal schemata in ESL reading. TESOL Quarterly, 21, 461-481.

6. Carell, P.L., Pharis, B., \& Liberto, J.( 1989).Metacognitive strategy training for ESL reading. TESOL Quarterly, 23/4, 647-678.

7. Chamot, A.U., Barnhardt, S, El-Dinary, P., \& Robbins, J. (1996). Methods of teaching learning strategies in the foreign language classroom. In R. L. Oxford (Ed.), Language learning strategies around the world: Cross-cultural perspectives (pp. 175-189). Second Language Teaching and Curriculum Center: University of Hawaii.

8. Chamot, A.U. \& O' Malley, J.M. (1996). Implementing the cognitive academic language approach (CALLA). In R. L. Oxford (Ed.), Language learning strategies around the world: Cross-cultural perspectives (pp. 167-175). Second Language Teaching and Curriculum Center: University of Hawaii.

9. Clarke, M.A., \& Silberstein, S. (1977).Toward a realization of psycholinguistic principles for the ESL reading class. Language Learning, 27,135-154.

10. Dadour, El S. \& Robbins, J. (1996). University level studies using strategy instruction to improve speaking ability in

Egypt and Japan. In R. L. Oxford (Ed.), Language learning strategies around the world: Cross-cultural perspectives (pp. 157-167). Second Language Teaching and Curriculum Center: University of Hawaii.

11. Dreyer, C.\& Oxford, R.L.(1996). Learning strategies and other predictors of ESL proficiency among Africaans speakers in South Africa. In R. L. Oxford (Ed.), Language learning strategies around the world: Cross-cultural perspectives ( $\mathrm{pp}$. 61-75). Second Language Teaching and Curriculum Center: University of Hawaii.

12. Goodman, K.S. (1967). Reading: A psycholinguistic guessing game. Journal of Reading Specialist, 6(1), 126-135.

13. Kaylani, C. (1996). The influence of gender and motivation on EFL learning strategy use in Jordan. In R. L. Oxford (Ed.), Language learning strategies around the world: Crosscultural perspectives ( $\mathrm{pp}$. 75-89). Second Language Teaching and Curriculum Center: University of Hawaii.

14. Levine , A., Reves, T., \& Leaver, B. L. (1996). Relationship between language learning strategies and Israeli versus Russian cultural- educational factors. In R. L. Oxford (Ed.), Language learning strategies around the world: Crosscultural perspectives (pp.19-35). Second Language Teaching and Curriculum Center : University of Hawaii.

15. Mokhtari, K. \& Sheorey, R. (2002, Spring). Measuring ESL students' awareness of reading strategies. Journal of Developmental Education, 25(3), 2-10.

16. Pritchard, R. (1990). The effects of cultural schemata on reading processing strategies. Reading Research Quarterly, 25, 273-295.

17. Sheorey, R. \& Mokhtari, K. (2001). Differences in the metacognitive awareness of reading strategies among native and non - native readers. Systems, 29, 431-449.

18. Widdowson, H.G. (1983). Learning purpose and language use. Oxford: Oxford University Press. 